\title{
Effect of Urea and Potassium Sulfate Fertilizers Combined with Boron on Soil Fertility and Sugar Beet Productivity in Salt Affected Soil
}

Rania M. EL-Shal

Soil and Water Dept., Faculty of Agriculture, Tanta University

\begin{abstract}
AIELD experiment was conducted an saline sodic soil at El-Quntra Shark, Ismailia governorate, Egypt, during two successive winter seasons of 2012/2013 and 2013/ 2014. It amid to evaluate the effect of urea and potassium sulfate fertilizers at different rates alone or combined with boron on some soil properties and its content of available nutrients and sugar beet productivity as well as the roots content of macronutrients and yield quality in salt affected soil. The soil has a sandy loam texture and is saline sodic $\left(\mathrm{EC}_{\mathrm{e}}=12.18 \mathrm{dS} / \mathrm{m}\right.$, $\mathrm{SAR}=22.78$ and $\mathrm{pH}=8.13)$. The experimental design was randomized complete block with three replicates. Urea and potassium sulfate fertilizers at three different rates, were arranged in the main treatment and applied in three equal doses after 30, 50 and 75 days from planting. The boron rates at 0.0 and $0.5 \mathrm{~kg}$ boric acid $\mathrm{fed}^{-1}$ in three doses at the same periods of $\mathrm{N}, \mathrm{K}$ application then randomly distributed in sub treatments.
\end{abstract}

Results showed that increasing $\mathrm{N}+\mathrm{K}_{2} \mathrm{O}$ fertilizers rates up to 150 $\mathrm{kg} \mathrm{N}$ and $100 \mathrm{~kg} \mathrm{~K}_{2} \mathrm{O}$.fed ${ }^{-1}$ combined with B significantly decreased soil salinity, and significantly increased the available $\mathrm{N}$ and $\mathrm{K}$, while $\mathrm{P}$ was not significantly affected. Sugar beet yield and yield quality as well as the nutrients content in root of sugar beet increased with increasing the rates of $\mathrm{N}+\mathrm{K}_{2} \mathrm{O}$ combined with $\mathrm{B}$. The maximum sugar beet yield of root (15.96 ton/fed), sugar yield (2.26 ton/fed), sucrose $(16.07 \%)$ and protein percentage $(13.13 \%)$ were achieved with $150 \mathrm{~kg} \mathrm{~N}+100 \mathrm{~kg} \mathrm{~K}_{2} \mathrm{O} /$ fed combined with $0.5 \mathrm{~kg} \mathrm{~B}$. fed ${ }^{-1}$. Also, application of $\mathrm{N}+\mathrm{K}_{2} \mathrm{O}$ rates had a significant positive effect on root fresh weight/plant, root diameter, and juice purity percentage in both seasons. Raising the $\mathrm{N}+\mathrm{K}_{2} \mathrm{O}$ fertilizers rates combined with $\mathrm{B}$ significantly augmented the content of $\mathrm{N}, \mathrm{P}$ and $\mathrm{K}$ in roots during the two growing seasons. The observation which ought to be mentioned herein that, the combination of $150 \mathrm{~kg} \mathrm{~N}+100 \mathrm{~kg} \mathrm{~K}_{2} \mathrm{O}_{\text {fed }}^{-1}$ with B at rate of $0.5 \mathrm{~kg} \mathrm{~B}$. fed ${ }^{-1}$ as foliar spray could be recommend to obtain economical yield with satisfactory quality and to improve the soil fertility under the conditions of the studied area.

Keywords: Saline sodic soil, Sugar beet, Urea fertilizer, Potassium sulfate , Boron.

Sugar beet could be extensively grown under the Egyptian condition because of its adaptation to a wide range of climate, tolerance to salinity and productivity which make it a good cash crop. Recently, in Egypt, sugar beet crop had an 
important role in the Egyptian crop rotation as a winter crop in poor sand, salt affected and calcareous soils. It is one of the most salt tolerant crop. But it is reported to be less tolerant of salinity during germination emergence and in the seedling stage (Maas, 1986). Also, it is far better than sugar can when water use efficiency is concerned, on kilogram of sugar needs about 1.4 and $4.0 \mathrm{~m}^{3}$ water by sugar beet and sugar cane, respectively, (Ouda, 2011). The productivity of crops and plants is severely limited under the saline soil conditions. It is demonstrated that the fertilization practices is an increasingly important tool for improving the salt affected soil and crop productivity in many areas of the world (Jordan et al., 2004). Adding suitable fertilizers, such as macro and or/micronutrients is one of the favorite factor for soil fertility and crop productivity.

Nitrogen and potassium fertilizers are essential for high root and sugar yields. Nitrogen is an essential element of bio-molecules such as amino acids, proteins, nucleic acids, phytohormones and a number of enzymes and coenzymes (Ashraf and Khan, 1993). Management of soil fertility especially for $\mathrm{N}$ and $\mathrm{K}$ in salt-affected soils is essential because these nutrients are required in high amounts for good crop growth and high production (Noaman, 2004). Amin (2005) reported that increasing $\mathrm{N}$ levels significantly increased root length and its diameter, root fresh weight, top, root and sugar yield. Seadh et al. (2007) found that the different combination levels between potassium sulfate and nitrogen increased significantly the concentration of nitrogen, potassium and phosphorus in sugar beet root. El-Sarag and Moselhy (2013) indicated that the application of $211 \mathrm{~kg} \mathrm{~N}$ and $180 \mathrm{~kg} \mathrm{~K}_{2} \mathrm{O}$ ha $^{-1}$ gave the highest top and root yields (19.21 and $\left.50.59 \mathrm{t} \mathrm{ha}^{-1}\right)$. On other hand, Buskiene and Uselis (2008) found that the nitrogen content in the soil increased by approximately $25 \%$. When the rate of potassium fertilizer was increased from 90 to $240 \mathrm{~kg} \mathrm{ha}^{-1}$, potassium content in the soil increased to $33 \%$. Mahmoud (2011) found that the soil $\mathrm{pH}$ and EC decrease with increasing potassium sulfate rate. Shaban et al. (2012) showed that, the micronutrient (Fe, Mn and $\mathrm{Zn}$ ) content in soil increased with increasing rates of $\mathrm{N}$ combined with $\mathrm{K}$ fertilizers,

Potassium fertilization for sugar beet crop became indispensable particularly in the saline soils. Potassium plays an important role to overcome the high concentration of sodium which has a deteriorating effect on root quality of sugar beet. The influence of $\mathrm{K}$ on sugar beet is a function of its root in several individual biochemical and biophysical processes. It directly and indirectly affects photosynthesis, movement and utilization of assimilates, water transport and osmoregulation turgor. The combined effects of which are manifested in both crop yield and quality. Therefore, sugar beet, has a high $\mathrm{K}$ requirement (Herlihy, 1989). Ibrahim et al. (2002) showed that the highest percentage of root yield (22\% and $24 \%)$ and that of white sugar yield $(25.4 \%$ and $37.7 \%)$ was obtained at addition of $96 \mathrm{~kg} \mathrm{~K}_{2} \mathrm{O}$. fed $^{-1}$, proving that $\mathrm{K}$-fertilization increment improve sugar quality more than that production quantity.

Egypt. J. Soil Sci. 56, No. 4 (2016) 
Boron (B) is the most important of the trace elements needed sugar beet because, without an adequate supply, the yield and quality of roots is very depressed (Cooke and Scott, 1993). Soil application, as well as, a foliar spray of boron is equally effective, hence the root fresh weight, sucrose \%, root and top yields significantly increased by increasing boron levels (Jaszczolt, 1998). It plays important role in water relations, cell wall formation; cations and anions absorption, pollen viability and metabolism of $\mathrm{N}, \mathrm{P}$, carbohydrates and fats in the plant (Oyinlola, 2007). Kristek et al. (2006) studied the effect of foliar fertilization with B element $(1.0 \mathrm{~kg} \mathrm{~B} / \mathrm{ha})$ on sugar beet root yield and quality compared to the control. They found that root yield is higher by $13.86 \mathrm{t} / \mathrm{ha}$ (19.4\%), sugar concentration higher by $1.46 \%$ (relative $10.8 \%$ ) and sugar yield higher by $3.15 \mathrm{t} / \mathrm{ha}$ (39.5\%). Azzazy (2004) found that the combined Boron and Nitrogen treatments at the rate of $100 \mathrm{~kg} \mathrm{~N}+5 \mathrm{~kg}$ borax are recommended to maximize quality and yield of sugar beet under the new reclaimed soil. Hellal $e t$ al. (2009) showed that the positive effect of increasing $\mathrm{N}$ doses on shoot and root weight may be due to the role of nitrogen in development and survival of new tillers, through synthesis of nucleic acids and other organelles. Boron found, also, to interact positively with nitrogen to affect yield and yield components of sugar beet. Combination of $50 \mathrm{ppm} \mathrm{B} \mathrm{plus} 100 \mathrm{mg} \mathrm{N} \mathrm{kg}^{-1}$ soil led to the highest values of shoot and root yield of sugar beet and nutrient balance whereas increasing the B application until $100 \mathrm{ppm}$ appeared to have a toxic effect on plant growth.

Therefore the current work was carried out to study the effect of potassium and nitrogen fertilization rates alone or combined with boron on yield and quality of sugar beet and on some soil properties and its content of available nutrients under saline sodic condition.

\section{Materials and Methods}

Two field experiments were conducted at El-Quntra Shark, Ismailia governorate, Egypt (latitude $30^{\circ} 80^{\circ} \mathrm{N}$ and longitude $32^{\circ} 28^{\circ} \mathrm{E}$ ), during two successive winter seasons 2012/2013 and 2013/ 2014. The experimental area is characterized by Mediterranean climate which is hot dry summer and relative cold winter. The mean annual rainfall is about $200 \mathrm{~mm}$ mostly fell in January and February. The soil has a sandy loam texture and is saline sodic $\left(\mathrm{EC}_{\mathrm{e}}=12.18\right.$ $\mathrm{dS} / \mathrm{m}, \mathrm{SAR}=22.78$ and $\mathrm{pH}(1: 2.5)=8.13)$. The nutritional status of the soil is generally low. Level of soil organic matter content $(0.45)$ is very low due to the climatic conditions of the studied area which favor its rapid decomposition. The $\mathrm{N}, \mathrm{P}$ and $\mathrm{K}$ contents are also little, Table 1. Some physical and chemical properties of the experimental soil were determined according to Kim (1996) and presented in Table 1.

The experiments were set up in a randomized complete block design with three replicates. Urea $(46 \% \mathrm{~N})$ and potassium sulfate $\left(48 \% \mathrm{~K}_{2} \mathrm{O}\right)$ fertilizers at three different rates $\left(75 \mathrm{~kg} \mathrm{~N}+50 \mathrm{~kg} \mathrm{~K}{ }_{2} \mathrm{O}, 100 \mathrm{~kg} \mathrm{~N}+75 \mathrm{~kg} \mathrm{~K}{ }_{2} \mathrm{O}\right.$ and $150 \mathrm{~kg}$ $\mathrm{N}+100 \mathrm{~kg} \mathrm{~K} \mathrm{O}_{\mathrm{fed}}{ }^{-1}$ ) in three equal doses after 30, 50 and 75 days from Egypt. J. Soil Sci. 56, No. 4 (2016) 
planting and arranged as a main treatments. The control received the recommended doses of $\mathrm{N}$ and $\mathrm{K}$ fertilizer. While the boron rates at 0.0 and 0.5 $\mathrm{kg} \mathrm{fed}^{-1}$ boric acid $(17.0 \% \mathrm{~B})$ were applied as a foliar spray in three doses after 30,50 and 75 days from planting and randomly distributed sub treatments.

Super phosphate $\left(15.5 \% \mathrm{P}_{2} \mathrm{O}_{2}\right)$ was applied at a rate $31 \mathrm{~kg} \mathrm{P}_{2} \mathrm{O}_{2} \cdot \mathrm{fed}^{-1}$ during soil preparation.

TABLE 1. Soil physical and chemical properties of the studied soil $(0-30 \mathrm{~cm})$ before planting

\begin{tabular}{|c|c|c|c|c|c|c|c|c|c|}
\hline \multicolumn{5}{|c|}{ Particle size distribution } & \multirow[b]{2}{*}{ Texture } & \multirow{2}{*}{\multicolumn{2}{|c|}{$\begin{array}{l}\text { O.M } \\
(\%)\end{array}$}} & \multirow[b]{2}{*}{$\begin{array}{c}\mathrm{CaCO}_{3} \\
(\%)\end{array}$} & \multirow[b]{2}{*}{ SAR } \\
\hline $\begin{array}{l}\text { Coarse } \\
\text { sand }(\%)\end{array}$ & $\begin{array}{l}\text { Fine } \\
\text { sand } \\
(\%)\end{array}$ & $\begin{array}{l}\text { Silt } \\
(\%)\end{array}$ & $\begin{array}{l}\text { Clay } \\
(\%)\end{array}$ & & & & & & \\
\hline 8.99 & 67.11 & 10.39 & 13.5 & & $\begin{array}{c}\text { Sandy } \\
\text { loam }\end{array}$ & 0.45 & & 7.00 & 22.78 \\
\hline \multirow{2}{*}{$\mathrm{pH}(1: 2: 5)$} & \multirow{2}{*}{$\begin{array}{c}\mathrm{EC} \\
(\mathrm{dS} / \mathrm{m})\end{array}$} & \multicolumn{4}{|c|}{ Cations (mmole/l) } & \multicolumn{4}{|c|}{ Anions (mmol/l) } \\
\hline & & $\mathrm{Ca}^{++}$ & $\mathrm{Mg}^{++}$ & $\mathrm{Na}^{+}$ & $\mathrm{K}^{+}$ & $\mathrm{HCO}_{3}^{-}$ & $\mathrm{Cl}^{-}$ & & $\mathrm{O}_{4}^{--}$ \\
\hline 8.13 & $\begin{array}{c}12.1 \\
8\end{array}$ & $\begin{array}{c}10.3 \\
9\end{array}$ & 20.83 & 90.0 & 0.88 & 7.93 & 80.0 & & 4.17 \\
\hline \multicolumn{3}{|c|}{ Macronutrients $(\mathrm{mg} / \mathrm{kg})$} & \multicolumn{7}{|c|}{ Micronutrients $(\mathrm{mg} / \mathrm{kg})$} \\
\hline $\mathrm{N}$ & $\mathrm{P}$ & $\mathrm{K}$ & $\mathrm{Fe}$ & & $\mathrm{Mn}$ & $\mathrm{Zn}$ & & $\mathrm{Cl}$ & \\
\hline 33.0 & 3.68 & 190 & 1.22 & & 2.11 & 0.62 & & 0.0 & \\
\hline
\end{tabular}

Sugar beet (Beta vulgaris L.), Mirador sugar beet variety was shown on October $28^{\text {th }}$ in growing seasons 2012 and 2013 respectively at rate of $4 \mathrm{~kg}$ seeds/fed and harvested after 170 days from sowing (on April $20^{\text {th }}$ in the two seasons). Each experimental plot consisted of 6 rows each of $4 \mathrm{~m}$ in length and $50 \mathrm{~cm}$ in width. The growth area plot was $12 \mathrm{~m}^{2}(4.0 \times 3.0 \mathrm{~m})$. Three seeds were sown in each hill, thinned after 30 days to one plant per hill. Sugar beet was irrigated by the furrow method and the irrigation water salinity was about $1.7 \mathrm{dS} / \mathrm{m}$. Water was applied immediately after sowing for 4 hours and then the excess water was drained. On day after the soil received the same amount of irrigation. After that, irrigation water was added every 12 days until the end of the growing seasons. This was done in order to get rid of a large part of the soluble salts in the soil (Shaban et al., 2012).

One day before harvesting, 5 plants with soil surrounding roots are taken from each plot. The plants were get rid of surrounding soil layer, washed, divided into roots and shoots and weighed. The yield of each plot was recorded as described by Shaban and Negm (2008). The root total soluble solids (T.S.S $\%)$ was determined using hand refractometer. Sucrose percent (\%) was determined in fresh samples of sugar beet root by using saccharometer according to the method described by AOAC (1995). Purity percentage was computed according to the equation: 


$$
\text { Purity } \%=\frac{\text { Sucrose } \%}{\text { T.S.S } \%} \times 100
$$

Total chlorophyll (mg/g f.w) was determined using spectrophotometric method described by Metzner et al. (1965).

Sugar beet plant samples were oven-dried at $70^{\circ} \mathrm{C}$ till a constant weight and the dry weight was recorded. The plant material was ground to a fine powder and sub sample of $0.2 \mathrm{~g}$ was wet disgusted using a mixture of $\mathrm{HClO}_{4}$ and $\mathrm{H}_{2} \mathrm{SO}_{4}$ acids to determine the concentration of $\mathrm{N} \mathrm{P} \mathrm{K}$ in the dry matter of plants as described by Cottenie et al. (1982).

Soil sample were collected at harvest from the surface layer $(0-30 \mathrm{~cm})$ to determine the salinity, $\mathrm{pH}$ and the available macronutrients $\mathrm{N} \mathrm{P} \mathrm{K}$ in the soil according to Kim (1996)

At harvest, random samples of sugar beet plants were taken from each plot to determine: Root length and diameter $(\mathrm{cm})$, as well as, root weight $(\mathrm{kg} / \mathrm{plant}$.). Root yield and Top yield (ton/fed). Sugar yield was also calculated by multiplying root yield (ton/fed) by Sucrose \%.

The obtained data of yield and nutrients analysis were statistically analyzed for the two seasons separately according to procedure of Snedecor and Cochran (1980).

\section{Results and Discussion}

\section{Soil salinity $\left(E C d S m^{-1}\right)$}

Soil salinity after harvesting sugar beet decreased significantly with increasing potassium sulfate combined with urea fertilizers compared with the control treatment, Table 2. Overall the average values of soil EC of soil treated with $\mathrm{N}+\mathrm{K}_{2} \mathrm{O}$ ranged from 5.91 to $7.51 \mathrm{dS} \mathrm{m}^{-1}$ was lower than that of the control treatment $(8.62 \mathrm{ds} / \mathrm{m})$. This means that potassium sulfate combined with urea fertilizers decreased EC values by about $12.8-30.7 \%$ relative to the control. The highest decrease induced with the highest rate. This may be resulted from the applied K-fertilizer which increase soil solution by $\mathrm{SO}_{4}{ }^{2}$ after its dissolution by the applied irrigation water (Khalifa and Ibrahim, 1995). These results are in agreement with Mahmoud (2011) who reported that the EC values decreased with increasing rates of potassium sulfate with the highest reduction at the highest rate, where a pronounced amount of salts leached out from the treated soil reflected on the associated soil properties. The obtained data showed, also, that EC values reduced by about $45 \%$ as compared with the corresponding initial soil before cultivation, and the $\mathrm{EC}$ values decline was more pronounced under the treatment of $\mathrm{N}+\mathrm{K}_{2} \mathrm{O}$ combined with boron. I.e., boron application enhanced the soil salinity reduction. These results are in agreement with those of Shaban et al. (2009) who found showed that the soil electrical conductivity (EC) values were reduced as compared with the corresponding initial soil before cultivation. Increasing the rate of nitrogen was associated with significant reduction in EC values. Tarek et al. (2008) found that the soil EC was significantly reduced from $60 \mathrm{dSm}^{-1}$ to about $17 \mathrm{dSm}^{-1}$, for the soil cultivated 
with fodder beet, and the harvested above ground biomass fodder beet removed $156 \mathrm{~kg} \mathrm{Na}^{+} \mathrm{ha}^{-1}$ from topsoil (0-10 $\mathrm{cm}$ deep).

TABLE 2. EC and the available macronutrients contents as affected by $N+K$ fertilizers combined with boron treatment

\begin{tabular}{|c|c|c|c|c|c|c|c|}
\hline \multirow{3}{*}{$\begin{array}{l}\text { Fertilizer } \\
\text { Treatments } \\
\text { (F) }\left(\mathbf{k g}^{\prime} \text { fed }^{-1}\right)\end{array}$} & \multicolumn{3}{|c|}{ Season 2012/2013 } & \multicolumn{3}{|c|}{ Season 2013/2014 } & \multirow{3}{*}{$\begin{array}{l}\text { Mean of two } \\
\text { seasons }\end{array}$} \\
\hline & \multicolumn{2}{|c|}{$\begin{array}{c}\text { Boric acid } \\
\left(\mathrm{kg}^{\left.-\mathrm{fed}^{-1}\right)}\right.\end{array}$} & \multirow{2}{*}{$\underset{\mathbf{F}}{\operatorname{Mean}}$} & \multicolumn{2}{|c|}{$\begin{array}{l}\text { Boric acid } \\
\left(\mathrm{kg}^{\left.- \text {fed }^{-1}\right)}\right)\end{array}$} & \multirow{2}{*}{$\underset{\mathbf{F}}{\text { Mean }}$} & \\
\hline & Non & 0.5 & & Non & 0.5 & & \\
\hline \multicolumn{8}{|c|}{$\mathrm{EC}$} \\
\hline Control & 9.17 & 8.94 & 9.06 & 8.79 & 7.58 & 8.19 & 8.62 \\
\hline $75 \mathrm{~N}+50 \mathrm{~K}_{2} \mathrm{O}$ & 8.44 & 7.48 & 7.96 & 7.86 & 6.25 & 7.06 & 7.51 \\
\hline $100 \mathrm{~N}+75 \mathrm{~K}_{2} \mathrm{O}$ & 7.59 & 7.14 & 7.37 & 6.02 & 5.88 & 5.95 & 6.66 \\
\hline $150 \mathrm{~N}+100 \mathrm{~K}_{2} \mathrm{O}$ & 6.71 & 6.10 & 6.41 & 5.83 & 5.22 & 5.53 & 5.97 \\
\hline Mean B & 7.98 & 7.42 & & 7.13 & 6.23 & & \\
\hline LSD. $\% 5 \mathrm{~F}$ & \multicolumn{3}{|c|}{0.66} & \multicolumn{3}{|c|}{0.25} & \\
\hline LSD. \%5 B & \multirow{2}{*}{\multicolumn{3}{|c|}{$\begin{array}{l}\mathrm{ns} \\
\mathrm{ns}\end{array}$}} & \multirow{2}{*}{\multicolumn{3}{|c|}{ ns }} & \\
\hline $\mathrm{F} \times \mathrm{B}$ & & & & \multicolumn{2}{|c|}{$* *$} & & \\
\hline \multicolumn{8}{|c|}{ Available Macronutrients (mg kg-1) } \\
\hline Control & 36.25 & 38.21 & 37.23 & 37.02 & 40.10 & 38.56 & 37.90 \\
\hline $75 \mathrm{~N}+50 \mathrm{~K}_{2} \mathrm{O}$ & 38.91 & 41.39 & 40.15 & 39.47 & 42.05 & 40.76 & 40.46 \\
\hline $100 \mathrm{~N}+75 \mathrm{~K}_{2} \mathrm{O}$ & 41.19 & 43.18 & 42.19 & 41.66 & 43.59 & 42.63 & 42.41 \\
\hline $150 \mathrm{~N}+100 \mathrm{~K}_{2} \mathrm{O}$ & 42.57 & 43.89 & 43.23 & 41.66 & 43.59 & 42.63 & 42.93 \\
\hline Mean B & 39.73 & 41.67 & & 43.01 & 44.28 & & \\
\hline LSD. $\% 5 \mathrm{~F}$ & \multirow{2}{*}{\multicolumn{3}{|c|}{1.46}} & \multicolumn{3}{|l|}{$\mathrm{ns}$} & \\
\hline LSD. \%5 B & & & & \multicolumn{3}{|l|}{ ns } & \\
\hline $\mathrm{F} \times \mathrm{B}$ & \multicolumn{3}{|l|}{$\mathrm{ns}$} & \multicolumn{3}{|l|}{ ns } & \\
\hline \multicolumn{8}{|c|}{$\mathrm{P}$} \\
\hline Control & 3.82 & 3.89 & 3.86 & 3.85 & 3.92 & 3.89 & 3.87 \\
\hline $75 \mathrm{~N}+50 \mathrm{~K}_{2} \mathrm{O}$ & 3.88 & 3.97 & 3.93 & 3.92 & 3.99 & 3.96 & 3.94 \\
\hline $100 \mathrm{~N}+75 \mathrm{~K}_{2} \mathrm{O}$ & 3.96 & 4.05 & 4.01 & 3.98 & 4.09 & 4.04 & 4.02 \\
\hline $150 \mathrm{~N}+100 \mathrm{~K}_{2} \mathrm{O}$ & 3.97 & 4.12 & 4.05 & 3.99 & 4.19 & 4.09 & 4.07 \\
\hline Mean B & 3.91 & 4.01 & & 3.94 & 4.05 & & \\
\hline LSD. $\% 5 \mathrm{~F}$ & \multicolumn{3}{|c|}{$\mathrm{ns}$} & \multicolumn{3}{|c|}{ ns } & \\
\hline LSD. \%5 B & \multicolumn{3}{|c|}{$\frac{\mathrm{ns}}{\mathrm{ns}}$} & & ns & & \\
\hline $\mathrm{F} \times \mathrm{B}$ & & $\mathrm{ns}$ & & & ns & & \\
\hline & & & $\mathrm{K}$ & & & & \\
\hline Control & 192 & 195 & 194 & 196 & 198 & 197 & 195 \\
\hline $75 \mathrm{~N}+50 \mathrm{~K}_{2} \mathrm{O}$ & 198 & 201 & 200 & 201 & 204 & 203 & 201 \\
\hline $100 \mathrm{~N}+75 \mathrm{~K}_{2} \mathrm{O}$ & 203 & 208 & 206 & 206 & 213 & 210 & 208 \\
\hline $150 \mathrm{~N}+100 \mathrm{~K}_{2} \mathrm{O}$ & 208 & 215 & 212 & 212 & 219 & 216 & 214 \\
\hline Mean B & 200 & 205 & & 204 & 209 & & \\
\hline LSD. $\% 5 \mathrm{~F}$ & & 3.76 & & & 2.62 & & \\
\hline LSD. $\% 5$ B & & 3.11 & & & 2.50 & & \\
\hline $\mathrm{F} \times \mathrm{B}$ & & ns & & & ns & & \\
\hline
\end{tabular}

The effect of interaction between the fertilizers was only significant in the $2^{\text {nd }}$ season, and the lowest EC value was obtained under the treatment of $\mathrm{N}+$ $\mathrm{K}_{2} \mathrm{O}$ at the highest rate with boron, whereas the highest one was recorded for the same treatment without boron. This may be ascribed to the ability of sugar beet to remove more of $\mathrm{Na}$ from the soil consequently decrease EC in the sodic saline soil (Tarek et al., 2008)

Content of the available macronutrients in soil under study

The data representing available $\mathrm{N}, \mathrm{P}$ and $\mathrm{K}$ as affected by $\mathrm{N}+\mathrm{K}_{2} \mathrm{O}$ rates applied alone or in combination with boron after sugar beet harvest are shown in Table 2. The available soil $\mathrm{N}$ and $\mathrm{K}$ increased significantly with the application of the $\mathrm{N}+\mathrm{K}_{2} \mathrm{O}$ fertilizers rates alone or combined with boron in both seasons, except the increment of $\mathrm{N}$ was not significant in the first season.

Egypt. J. Soil Sci. 56, No. 4 (2016) 
The available $\mathrm{P}$ increased also under all treatments but the increment was not significant in both seasons. However, the application of $\mathrm{N}+\mathrm{K}_{2} \mathrm{O}$ fertilizers at the high rates in combination with boron gave the highest soil available $\mathrm{N}, \mathrm{P}$ and $\mathrm{K}$. The interaction between different rates of $\mathrm{N}+\mathrm{K}$ and $\mathrm{B}$ were not significant in both season for available $\mathrm{N}, \mathrm{P}$ and $\mathrm{K}$ content in soil. The corresponding relative increase resulted from the fertilizers rates were 6.54, 10.80 and $12.61 \%$ for the available $\mathrm{N}$ with boron, while it was $6.95 ; 13.07$ and $16.78 \%$ without boron compared with the control, respectively, for the treatment of $\left(75 \mathrm{~kg} \mathrm{~N}+50 \mathrm{~kg} \mathrm{~K}{ }_{2} \mathrm{O}, 100 \mathrm{~kg} \mathrm{~N}+75 \mathrm{~kg} \mathrm{~K} \mathrm{O}_{2} \mathrm{O}\right.$ and $150 \mathrm{~kg} \mathrm{~N}+100$ $\mathrm{kg} \mathrm{K}_{2} \mathrm{O}$.fed ${ }^{-1}$ ). The corresponding relative increase for the same fertilizers rates were $1.79,4.09$ and $8.93 \%$ for $P$ content in soil with boron, and 1.56, 3.38 and $3.65 \%$ without boron compared with control , respectively. Concerning, the relative increase of the available $\mathrm{K}$ as affected by the fertilizers rates, were 3.04; 7.11 and $10.14 \%$ for soil treated with boron, while it was 3.09; 5.07 and $8.25 \%$ for soil without boron compared with control, respectively for the same fertilizer treatments. These finding indicate either that more $\mathrm{N}+\mathrm{K}_{2} \mathrm{O}$ applications, the more available nutrients increases, since the highest increase was noticed at the highest rates and these increments were enhanced with boron or to decline the $\mathrm{pH}$ that augment the availability of nutrients in the soil. Similar results were obtained by Shaban et al. (2013) who found that the rates of N + K were significantly affected soil contents of $\mathrm{K}$, while the $\mathrm{P}$ was not significantly affected. Helmy and Shaban (2007) indicates that the applied K fertilizer as well as foliar application with B increased the available N, P and K contents in soil as compared to the control. Singh and Sharma (2001) indicated that application of $\mathrm{N}$ and $\mathrm{K}$ fertilizers led to an increase of available $\mathrm{N}$ and $\mathrm{K}$ in surface soil. Also, Buskiene and Uselis (2008) reported that increasing the application rates of nitrogen fertilizer from 60 to $90 \mathrm{~kg} \mathrm{ha}^{-1}$, increased nitrogen content in the soil by approximately $25 \%$. When the rate of potassium fertilizer was increased from 90 to $240 \mathrm{~kg} \mathrm{~K}_{2} \mathrm{O} \mathrm{ha}^{-1}$, potassium content in the soil increased up to $33 \%$.

\section{Macronutrients (N, $P$ and $K)$ concentration in sugar beet root}

The obtained results presented in Table 3 showed that the application of $\mathrm{N}+$ $\mathrm{K}_{2} \mathrm{O}$ fertilizers alone or with boron caused a positive effect on $\mathrm{N}, \mathrm{P}$ and $\mathrm{K}$ concentration in sugar beet root as compared with the control treatment. $\mathrm{N}$ concentration of roots significantly increased in the $1^{\text {st }}$ season only, whereas the increase of $\mathrm{K}$ content was significant only in the $2^{\text {nd }}$ season. The $\mathrm{P}$ concentration significantly increased in both seasons. However, the highest increases of N, P and $\mathrm{K}$ concentrations were noticed at the highest rate of $\mathrm{N}+\mathrm{K}_{2} \mathrm{O}$ fertilizers in combination with boron. Overall average, $\mathrm{N}$ concentration in sugar beet roots increased by 22.7 and $11.7 \%$ over the control treatment at the highest and lowest rate of $\mathrm{N}+\mathrm{K}_{2} \mathrm{O}$, respectively. The corresponding values of $\mathrm{P}$ increase were 55.3 and $32.1 \%$ for the same treatments, respectively, while those of $\mathrm{K}$ were 27.2 and $10.7 \%$, respectively for the same treatments. In the same context, the relative increase of the $\mathrm{N}, \mathrm{P}$ and $\mathrm{K}$ concentration in sugar beet roots due to boron application were $8.47,22.4$ and $9.15 \%$, respectively. These results indicate that $\mathrm{P}$ responses more than $\mathrm{N}$ and $\mathrm{K}$ to the applied fertilizers. The interaction between $\mathrm{N}+\mathrm{K}_{2} \mathrm{O}$ fertilizers and $\mathrm{B}$ application significantly increased the N, P and K concentration of roots in the two seasons of the study, except the increment of $\mathrm{N}$ concentration was significant only in the $2^{\text {nd }}$ season, 
with the highest values at the highest rate of $\mathrm{N}+\mathrm{K}_{2} \mathrm{O}$ in combination with boron. This may be attributed to the beneficial and mutual affect applied nutrients on its availability in soil consequently, enhance its uptake and concentration in plant roots. These results are in agreement with thoses of Seadh et al. (2007) Salem and Khaled, (2012) and Shaban et al. (2013) who found that the different combination levels between potassium sulfate and nitrogen increased significantly the concentration of nitrogen, potassium and phosphorus in sugar beat root in two seasons of study. Also, Mehran and Samad (2013) showed that increasing $\mathrm{N}$ and $\mathrm{K}$ fertilization had a significant effect on nutrients content and uptake of roots and foliage over two seasons of study. In the same context, Hellal et al. (2009) found that the highest levels of boron and $\mathrm{N}$ application led to increase the N, P and K contents in root of sugar beet.

TABLE 3. Macronutrients concentration in root sugar beet as affected by $N+K$ fertilizers combined with boron treatment

\begin{tabular}{|c|c|c|c|c|c|c|c|}
\hline \multirow{3}{*}{$\begin{array}{c}\text { Fertilizer } \\
\text { Treatments } \\
\text { (F) }\left(\mathbf{k g} / \text { fed }^{-1}\right)\end{array}$} & \multicolumn{3}{|c|}{ Season 2012/2013 } & \multicolumn{3}{|c|}{ Season $2013 / 2014$} & \multirow{3}{*}{$\begin{array}{l}\text { Mean of two } \\
\text { seasons }\end{array}$} \\
\hline & \multicolumn{2}{|c|}{$\begin{array}{c}\text { Boric acid } \\
\left(\mathrm{kg}^{\prime} / \mathrm{fed}^{-1}\right)\end{array}$} & \multirow{2}{*}{$\begin{array}{c}\text { Mean } \\
\text { F }\end{array}$} & \multicolumn{2}{|c|}{$\begin{array}{c}\text { Boric acid } \\
\left(\mathrm{kg} / \mathrm{fed}^{-1}\right)\end{array}$} & \multirow[t]{2}{*}{ Mean $\mathbf{F}$} & \\
\hline & Non & 0.5 & & Non & 0.5 & & \\
\hline \multicolumn{8}{|c|}{$\mathbf{N}$} \\
\hline Control & 1.52 & 1.69 & 1.61 & 1.60 & 1.72 & 1.66 & 1.63 \\
\hline $75 \mathrm{~N}+50 \mathrm{~K}_{2} \mathrm{O}$ & 1.74 & 1.85 & 1.80 & 1.79 & 1.90 & 1.85 & 1.82 \\
\hline $100 \mathrm{~N}+75 \mathrm{~K}_{2} \mathrm{O}$ & 1.82 & 1.98 & 1.90 & 1.88 & 2.03 & 1.96 & 1.93 \\
\hline $150 \mathrm{~N}+100 \mathrm{~K} 2 \mathrm{O}$ & 1.87 & 2.08 & 1.98 & 1.92 & 2.12 & 2.02 & 2.00 \\
\hline Mean B & 1.74 & 1.90 & & 1.80 & 1.94 & & \\
\hline LSD. $\% 5 \mathrm{~F}$ & \multicolumn{3}{|c|}{0.05} & \multicolumn{3}{|c|}{$\mathrm{ns}$} & \\
\hline LSD. \%5 B & \multicolumn{3}{|c|}{0.018} & \multicolumn{3}{|c|}{ ns } & \\
\hline $\mathrm{F} \times \mathrm{B}$ & \multicolumn{3}{|c|}{$* *$} & \multicolumn{3}{|c|}{ ns } & \\
\hline \multicolumn{8}{|c|}{$\mathrm{P}$} \\
\hline Control & 0.39 & 0.69 & 0.54 & 0.43 & 0.72 & 0.58 & 0.56 \\
\hline $75 \mathrm{~N}+50 \mathrm{~K}_{2} \mathrm{O}$ & 0.67 & 0.77 & 0.72 & 0.71 & 0.81 & 0.76 & 0.74 \\
\hline $100 \mathrm{~N}+75 \mathrm{~K}_{2} \mathrm{O}$ & 0.76 & 0.83 & 0.80 & 0.81 & 0.87 & 0.84 & 0.82 \\
\hline $150 \mathrm{~N}+100 \mathrm{~K}_{2} \mathrm{O}$ & 0.79 & 0.89 & 0.84 & 0.85 & 0.96 & 0.91 & 0.87 \\
\hline Mean B & 0.65 & 0.80 & & 0.70 & 0.84 & & \\
\hline LSD. $\% 5 \mathrm{~F}$ & \multicolumn{3}{|c|}{0.010} & \multicolumn{3}{|c|}{0.014} & \\
\hline LSD. $\% 5$ B & \multicolumn{3}{|c|}{0.008} & \multicolumn{3}{|c|}{0.015} & \\
\hline $\mathrm{F} \times \mathrm{B}$ & \multicolumn{3}{|c|}{$* *$} & \multicolumn{3}{|c|}{$* *$} & \\
\hline \multicolumn{8}{|c|}{$\mathrm{K}$} \\
\hline Control & 2.79 & 2.94 & 2.87 & 2.83 & 3.05 & 2.94 & 2.90 \\
\hline $75 \mathrm{~N}+50 \mathrm{~K}_{2} \mathrm{O}$ & 2.98 & 3.34 & 3.16 & 3.07 & 3.46 & 3.27 & 3.21 \\
\hline $100 \mathrm{~N}+75 \mathrm{~K}_{2} \mathrm{O}$ & 3.22 & 3.55 & 3.39 & 3.48 & 3.74 & 3.61 & 3.50 \\
\hline $150 \mathrm{~N}+100 \mathrm{~K}_{2} \mathrm{O}$ & 3.47 & 3.77 & 3.62 & 3.69 & 3.82 & 3.76 & 3.69 \\
\hline Mean B & 3.12 & 3.40 & & 3.27 & 3.52 & & \\
\hline LSD. $\% 5 \mathrm{~F}$ & \multicolumn{3}{|c|}{ ns } & \multicolumn{3}{|c|}{0.019} & \\
\hline LSD. \%5 B & \multicolumn{3}{|c|}{0.007} & \multicolumn{3}{|c|}{0.020} & \\
\hline $\mathrm{F} \times \mathrm{B}$ & \multicolumn{3}{|c|}{$* *$} & \multicolumn{3}{|c|}{$* *$} & \\
\hline
\end{tabular}

Egypt. J. Soil Sci. 56, No. 4 (2016) 


\section{Yield and yield component of sugar beet}

The obtained results showed that $\mathrm{N}+\mathrm{K}_{2} \mathrm{O}$ fertilizers with or without boron had a significant positive effect on sugar beet yield and its component such as roots, top yield and sugar yield, (Table 4,) as well as, root fresh weight and root diameter, (Table 5). These parameters of yield and its component were found to be increased significantly with the incremental addition of applied fertilizers. The interaction effect between $\mathrm{N}+\mathrm{K}_{2} \mathrm{O}$ combined with boron fertilizers was found to be significant in respect to root and sugar yield in both seasons, but not significant in the $1^{\text {st }}$ season in respect to the root fresh weight and root diameter. A gradual increase was observed in root yield, top yield, sugar yield, root fresh weight and root diameter as reason of increasing nitrogen and potassium combination rates from $75 \mathrm{~kg} \mathrm{~N}+50 \mathrm{~kg} \mathrm{~K}_{2} \mathrm{O}$ fed $^{-1}$ to $150 \mathrm{~kg} \mathrm{~N}+100 \mathrm{~kg} \mathrm{~K}_{2} \mathrm{O}$ $\mathrm{fed}^{-1}$ alone or combined with $\mathrm{B}$ in both seasons. The highest increase occurred at the highest rates of the applied fertilizers. Average values of root fresh weight and root diameter increased by 40.5 and by $45.5 \%$ for the root fresh weight and by 57.3 and $36.3 \%$ for the root diameter, relative to the control treatment, affected by the treatment of the highest fertilizers rates with and without boron, respectively. Likewise, the average values, over the two seasons, increased from 10.13 to 15.96 , from 12.7 to 14.35 and from 1.98 to $2.56{\mathrm{Mg} . f e d^{-1}}^{-}$, for root, top

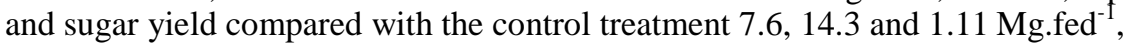
respectively, under the treatment of the highest fertilizers rates with boron,. The corresponding values at the same treatment without boron were varied from

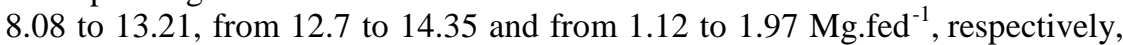
for the same traits compared with the control treatment $6.98,10.45$ and 0.92 ${\mathrm{Mg} . \mathrm{fed}^{-1}}^{-1}$, respectively. Such as effect of nitrogen and potassium on these parameters may be returned to its role in building up metabolites and activation of enzymes that associate with accumulation of carbohydrates, which transported from leaves to developing roots. These results means that root yield at the highest application rate $150 \mathrm{~kg} \mathrm{~N}+100 \mathrm{~kg} \mathrm{~K}_{2} \mathrm{O} /$ fed increased by $109.86 \%$ and $89.33 \%$, respectively, with and without boron relative to the control. The corresponding values for the sugar yield at the same treatment with and without boron were $130.6 \%$ and $114.1 \%$, respectively. As for the top yield, the relative increase, over the two season at the highest application rate $150 \mathrm{~kg} \mathrm{~N}$ $+100 \mathrm{~kg} \mathrm{~K}_{2} \mathrm{O} /$ fed with and without boron were $17.5 \%$ and $37.3 \%$, respectively. These results emphasize the beneficial role of boron in improving the productivity of sugar beet crop.

The same trend of the obtained results was reported by El-Sarag and Sameh (2013) who found that application of $211 \mathrm{~kg} \mathrm{~N}$ and $180 \mathrm{~kg} \mathrm{~K}_{2} \mathrm{O} \mathrm{ha}{ }^{-1}$ gave the highest top and root yields (19.21 and 50.59 ton $\mathrm{ha}^{-1}$ ) while, the lowest quantities of sugar beet top and root $\left(9.71\right.$ and 25.43 ton ha ${ }^{-1}$ ) were achieved by adding $105 \mathrm{~kg} \mathrm{~N}$ and $60 \mathrm{~kg} \mathrm{~K}_{2} \mathrm{O} \mathrm{ha}^{-1}$. On other hand, the obtained increases with $\mathrm{K}$ application could be due to its effective role on carbohydrate and $\mathrm{N}$ metabolism, water absorption and transpiration in plant. Abdel- Mawly and Zanouny (2004) indicated that application of $\mathrm{K}$ tends to accelerate photosynthetic activity, translocation of sucrose from the leaves and its accumulation in roots. The beneficial effects of $\mathrm{K}$ in improving sugar beet productivity may be attributed to its enhancement effects on increasing plant metabolic activity. 
TABLE 4. Yield and yield component as affected with $N+K$ combined with or without boron

\begin{tabular}{|c|c|c|c|c|c|c|c|}
\hline \multirow{3}{*}{ 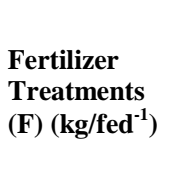 } & \multicolumn{3}{|c|}{ Season $2012 / 2013$} & \multicolumn{3}{|c|}{ Season $2013 / 2014$} & \multirow{3}{*}{$\begin{array}{c}\text { Mean of two } \\
\text { seasons }\end{array}$} \\
\hline & \multicolumn{2}{|c|}{ 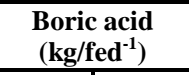 } & \multirow{2}{*}{$\begin{array}{c}\text { Mean } \\
\text { F }\end{array}$} & \multicolumn{2}{|c|}{ 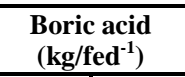 } & \multirow{2}{*}{ Mean $\mathbf{F}$} & \\
\hline & Non & 0.5 & & Non & 0.5 & & \\
\hline \multicolumn{8}{|c|}{ Weight root yield $\left(\mathrm{Mg} \mathrm{fed}^{-1}\right)$} \\
\hline Control & 6.71 & 7.38 & 7.05 & 7.25 & 7.83 & 7.54 & 7.29 \\
\hline $75 \mathrm{~N}+50 \mathrm{~K}_{2} \mathrm{O}$ & 7.82 & 9.68 & 8.75 & 8.34 & 10.59 & 9.47 & 9.11 \\
\hline $100 \mathrm{~N}+75 \mathrm{~K}_{2} \mathrm{O}$ & 9.60 & 12.95 & 11.28 & 11.52 & 15.74 & 13.63 & 12.45 \\
\hline $150 \mathrm{~N}+100 \mathrm{~K}_{2} \mathrm{O}$ & 12.74 & 14.98 & 13.86 & 13.69 & 16.94 & 15.32 & 14.59 \\
\hline Mean B & 9.22 & 11.25 & & 10.20 & 12.78 & & \\
\hline LSD. $\% 5 \mathrm{~F}$ & \multicolumn{3}{|c|}{0.64} & \multicolumn{3}{|c|}{1.90} & \\
\hline LSD. $\% 5 \mathrm{~B}$ & \multicolumn{3}{|c|}{0.45} & \multicolumn{3}{|c|}{1.34} & \\
\hline $\mathrm{F} \times \mathrm{B}$ & \multicolumn{3}{|c|}{$* *$} & \multicolumn{3}{|c|}{ ns } & \\
\hline \multicolumn{8}{|c|}{ Top yield $\left(\mathrm{Mg} \mathrm{fed}^{-1}\right)$} \\
\hline Control & 10.25 & 14.12 & 12.19 & 10.66 & 14.55 & 12.61 & 12.40 \\
\hline $75 \mathrm{~N}+50 \mathrm{~K}_{2} \mathrm{O}$ & 12.54 & 14.97 & 13.76 & 12.86 & 15.05 & 13.96 & 13.86 \\
\hline $100 \mathrm{~N}+75 \mathrm{~K}_{2} \mathrm{O}$ & 13.14 & 15.77 & 14.46 & 13.82 & 16.43 & 15.13 & 14.79 \\
\hline $150 \mathrm{~N}+100 \mathrm{~K}_{2} \mathrm{O}$ & 13.96 & 16.46 & 15.21 & 14.74 & 17.23 & 15.99 & 15.60 \\
\hline Mean B & 12.47 & 15.33 & & 13.02 & 15.82 & & \\
\hline LSD. $\% 5 \mathrm{~F}$ & \multicolumn{3}{|c|}{1.92} & \multicolumn{3}{|c|}{1.75} & \\
\hline LSD. $\% 5$ B & \multicolumn{3}{|c|}{1.36} & \multicolumn{3}{|c|}{1.24} & \\
\hline $\mathrm{F} \times \mathrm{B}$ & \multicolumn{3}{|c|}{ ns } & \multicolumn{3}{|c|}{ ns } & \\
\hline \multicolumn{8}{|c|}{ Sugar yield $\left(\mathrm{Mg} \mathrm{fed}^{-1}\right)$} \\
\hline Control & 0.87 & 1.07 & 0.97 & 0.97 & 1.15 & 1.06 & 1.02 \\
\hline $75 \mathrm{~N}+50 \mathrm{~K}_{2} \mathrm{O}$ & 1.08 & 1.46 & 1.27 & 1.16 & 2.51 & 1.84 & 1.55 \\
\hline $100 \mathrm{~N}+75 \mathrm{~K}_{2} \mathrm{O}$ & 1.37 & 2.06 & 1.72 & 1.70 & 2.51 & 2.11 & 1.91 \\
\hline $150 \mathrm{~N}+100 \mathrm{~K}_{2} \mathrm{O}$ & 1.89 & 2.40 & 2.15 & 2.05 & 2.72 & 2.39 & 2.27 \\
\hline Mean B & 1.30 & 1.75 & & 1.47 & 2.22 & & \\
\hline LSD. $\% 5 \mathrm{~F}$ & \multicolumn{3}{|c|}{0.07} & \multicolumn{3}{|c|}{0.05} & \\
\hline LSD. $\% 5$ B & \multicolumn{3}{|c|}{0.05} & \multicolumn{3}{|c|}{0.03} & \\
\hline $\mathrm{F} \times \mathrm{B}$ & \multicolumn{3}{|c|}{$* *$} & \multicolumn{3}{|c|}{$* *$} & \\
\hline
\end{tabular}

Egypt. J. Soil Sci. 56, No. 4 (2016) 
The positive effect of $\mathrm{N}$ fertilizer might be due to the increased efficiency of $\mathrm{N}$-fertilization in building up metabolites translocations from leaves to developing roots, thus increases dry matter accumulation.

TABLE 5. Root fresh weight and root diameter as affected with $N+K$ combined with or without boron

\begin{tabular}{|c|c|c|c|c|c|c|c|}
\hline \multirow{3}{*}{$\begin{array}{l}\text { Fertilizer } \\
\text { Treatments } \\
\text { (F) }\left(\mathbf{k g}^{\left.- \text {fed }^{-1}\right)}\right.\end{array}$} & \multicolumn{3}{|c|}{ Season 2012/2013 } & \multicolumn{3}{|c|}{ Season 2013/2014 } & \multirow{3}{*}{$\begin{array}{c}\text { Mean of } \\
\text { two seasons }\end{array}$} \\
\hline & \multicolumn{2}{|c|}{ 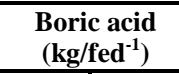 } & \multirow{2}{*}{$\begin{array}{c}\text { Mean } \\
\text { F }\end{array}$} & \multicolumn{2}{|c|}{$\begin{array}{c}\begin{array}{c}\text { Boric acid } \\
\left(\mathrm{kg}^{\prime} \mathrm{fed}^{-1}\right)\end{array} \\
\end{array}$} & \multirow{2}{*}{ Mean $\mathbf{F}$} & \\
\hline & Non & 0.5 & & Non & 0.5 & & \\
\hline \multicolumn{8}{|c|}{ Root fresh weight ( $\mathrm{g} / \mathrm{plant})$} \\
\hline Control & 512 & 559 & 536 & 529 & 573 & 551 & 543 \\
\hline $75 \mathrm{~N}+50 \mathrm{~K}_{2} \mathrm{O}$ & 573 & 637 & 605 & 596 & 720 & 658 & 632 \\
\hline $100 \mathrm{~N}+75 \mathrm{~K}_{2} \mathrm{O}$ & 637 & 748 & 693 & 649 & 793 & 721 & 707 \\
\hline $150 \mathrm{~N}+100 \mathrm{~K}_{2} \mathrm{O}$ & 720 & 788 & 754 & 791 & 803 & 797 & 776 \\
\hline Mean B & 611 & 683 & & 641 & 722 & & \\
\hline LSD. $\% 5 \mathrm{~F}$ & \multicolumn{3}{|l|}{41.46} & \multicolumn{3}{|l|}{41.65} & \\
\hline LSD. $\% 5$ B & \multicolumn{3}{|l|}{29.32} & \multicolumn{3}{|l|}{29.46} & \\
\hline $\mathrm{F} \times \mathrm{B}$ & \multicolumn{3}{|l|}{ ns } & \multicolumn{3}{|l|}{$* *$} & \\
\hline \multicolumn{8}{|c|}{ Root diameter $(\mathrm{cm})$} \\
\hline Control & 6.14 & 6.27 & 6.21 & 7.15 & 7.33 & 7.24 & 6.72 \\
\hline $75 \mathrm{~N}+50 \mathrm{~K}_{2} \mathrm{O}$ & 8.04 & 8.35 & 8.20 & 8.15 & 8.67 & 8.41 & 8.30 \\
\hline $100 \mathrm{~N}+75 \mathrm{~K}_{2} \mathrm{O}$ & 8.38 & 8.96 & 8.67 & 8.91 & 9.28 & 9.10 & 8.88 \\
\hline $150 \mathrm{~N}+100 \mathrm{~K}_{2} \mathrm{O}$ & 8.96 & 10.53 & 9.75 & 9.15 & 10.88 & 10.02 & 9.88 \\
\hline Mean B & 7.88 & 8.53 & & 8.34 & 9.04 & & \\
\hline LSD. $\% 5 \mathrm{~F}$ & \multicolumn{3}{|c|}{0.65} & \multicolumn{3}{|c|}{0.55} & \\
\hline LSD. $\% 5$ B & \multicolumn{3}{|c|}{0.44} & \multicolumn{3}{|c|}{0.39} & \\
\hline $\mathrm{F} \times \mathrm{B}$ & \multicolumn{3}{|c|}{$\mathrm{ns}$} & \multicolumn{3}{|c|}{$*$} & \\
\hline
\end{tabular}

According to the above mentioned results, the combination of $150 \mathrm{~kg} \mathrm{~N}+$ $100 \mathrm{~kg} \mathrm{~K}_{2} \mathrm{O} \mathrm{fed}{ }^{-1}$ with boron at rate of $0.5 \mathrm{~kg} \mathrm{~B} \mathrm{fed}^{-1}$ as foliar spray could be recommended to maximize the sugar beet productivity and to improve the soil fertility under the conditions of the studied area.

\section{Yield quality of sugar beet}

The studied sugar beet quality such as sucrose percentage, purity (\%), protein percentage and total chlorophyll $(\mathrm{mg} / \mathrm{g})$ are shown in Table 6. Results revealed that all sugar beet quality parameters were significantly increased as affected by the different application rates of $\mathrm{N}+\mathrm{K}_{2} \mathrm{O}$ in both seasons, with the highest increase at the highest application of fertilizers rates, except sucrose (\%) which was not significantly affected. Also, the application of boron affected significantly the studied quality traits. The interaction between the $\mathrm{N}+\mathrm{K}_{2} \mathrm{O}$ different rates and $\mathrm{B}$ was not significantly affected the studied quality 
parameters in both seasons, except of the total chlorophyll which was affected significantly in the $1^{\text {st }}$ season only.

TABLE 6. Effect of mineral nitrogen and potassium fertilizers alone or combined with boron on sugar beet quality under saline soil

\begin{tabular}{|c|c|c|c|c|c|c|c|}
\hline \multirow{3}{*}{$\begin{array}{l}\text { Fertilizer } \\
\text { Treatments } \\
\text { (F) }\left(\mathrm{kg}^{\left.- \text {fed }^{-1}\right)}\right.\end{array}$} & \multicolumn{3}{|c|}{ Season 2012/2013 } & \multicolumn{3}{|c|}{ Season 2013/2014 } & \multirow{3}{*}{$\begin{array}{c}\text { Mean of two } \\
\text { seasons }\end{array}$} \\
\hline & \multicolumn{2}{|c|}{ 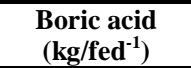 } & \multirow{2}{*}{$\underset{\mathbf{F}}{\text { Mean }}$} & \multicolumn{2}{|c|}{ 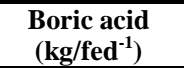 } & \multirow[t]{2}{*}{ Mean $\mathbf{F}$} & \\
\hline & Non & 0.5 & & Non & 0.5 & & \\
\hline \multicolumn{8}{|c|}{ Total Chlorophyll (mg/g F.W) } \\
\hline Control & 569 & 579 & 574 & 573 & 583 & 578 & 576 \\
\hline $75 \mathrm{~N}+50 \mathrm{~K}_{2} \mathrm{O}$ & 689 & 720 & 705 & 702 & 735 & 719 & 712 \\
\hline $100 \mathrm{~N}+75 \mathrm{~K}_{2} \mathrm{O}$ & 743 & 758 & 751 & 759 & 782 & 771 & 761 \\
\hline $150 \mathrm{~N}+100 \mathrm{~K}_{2} \mathrm{O}$ & 743 & 812 & 778 & 759 & 820 & 790 & 784 \\
\hline Mean B & 686 & 717 & & 698 & 730 & & \\
\hline LSD. $\% 5 \mathrm{~F}$ & \multicolumn{3}{|c|}{8.34} & \multicolumn{3}{|c|}{42.16} & \\
\hline LSD. \%5 B & \multicolumn{3}{|c|}{5.9} & \multicolumn{3}{|c|}{29.15} & \\
\hline $\mathrm{F} \times \mathrm{B}$ & \multicolumn{3}{|c|}{$* *$} & \multicolumn{3}{|c|}{ ns } & \\
\hline \multicolumn{8}{|c|}{ Sucrose $(\%)$} \\
\hline Control & 13.22 & 14.52 & 13.87 & 13.39 & 14.80 & 14.10 & 13.98 \\
\hline $75 \mathrm{~N}+50 \mathrm{~K}_{2} \mathrm{O}$ & 13.92 & 15.10 & 14.51 & 14.02 & 15.59 & 14.81 & 14.66 \\
\hline $100 \mathrm{~N}+75 \mathrm{~K}_{2} \mathrm{O}$ & 14.37 & 15.95 & 15.16 & 14.80 & 15.99 & 15.40 & 15.28 \\
\hline $150 \mathrm{~N}+100 \mathrm{~K}_{2} \mathrm{O}$ & 14.90 & 16.06 & 15.48 & 15.02 & 16.08 & 15.55 & 15.52 \\
\hline Mean B & 14.10 & 15.41 & & 14.31 & 15.62 & & \\
\hline LSD. $\% 5 \mathrm{~F}$ & \multicolumn{3}{|c|}{ ns } & \multicolumn{3}{|c|}{$\mathrm{ns}$} & \\
\hline LSD. $\% 5$ B & \multicolumn{3}{|c|}{1.16} & & & & \\
\hline $\mathrm{F} \times \mathrm{B}$ & & $* *$ & & \multicolumn{3}{|c|}{$\mathrm{ns}$} & \\
\hline \multicolumn{8}{|c|}{ Purity $(\%)$} \\
\hline Control & 73.55 & 75.96 & 74.76 & 75.18 & 78.14 & 76.66 & 75.71 \\
\hline $75 \mathrm{~N}+50 \mathrm{~K}_{2} \mathrm{O}$ & 77.96 & 82.53 & 80.25 & 82.60 & 83.10 & 82.85 & 81.55 \\
\hline $100 \mathrm{~N}+75 \mathrm{~K}_{2} \mathrm{O}$ & 85.17 & 87.21 & 86.19 & 86.77 & 89.25 & 88.01 & 87.10 \\
\hline $150 \mathrm{~N}+100 \mathrm{~K}_{2} \mathrm{O}$ & 82.15 & 86.14 & 84.15 & 84.09 & 88.02 & 86.06 & 85.10 \\
\hline Mean B & 79.71 & 82.96 & & 82.16 & 84.63 & & \\
\hline LSD. $\% 5 \mathrm{~F}$ & \multicolumn{3}{|c|}{1.85} & \multicolumn{3}{|c|}{1.72} & \\
\hline LSD. \%5 B & \multicolumn{3}{|c|}{1.31} & \multicolumn{3}{|c|}{1.22} & \\
\hline $\mathrm{F} \times \mathrm{B}$ & \multicolumn{3}{|c|}{ ns } & & $\mathrm{ns}$ & & \\
\hline & & & Pro & $\mathrm{n}(\%)$ & & & \\
\hline Control & 9.50 & 10.56 & 10.03 & 10.00 & 10.75 & 10.38 & 10.20 \\
\hline $75 \mathrm{~N}+50 \mathrm{~K}_{2} \mathrm{O}$ & 10.88 & 11.56 & 11.22 & 11.19 & 11.88 & 11.54 & 11.38 \\
\hline $100 \mathrm{~N}+75 \mathrm{~K}_{2} \mathrm{O}$ & 11.38 & 12.38 & 11.88 & 11.75 & 12.69 & 12.22 & 12.05 \\
\hline $150 \mathrm{~N}+100 \mathrm{~K}_{2} \mathrm{O}$ & 11.69 & 13.00 & 12.35 & 12.00 & 13.25 & 12.63 & 12.49 \\
\hline Mean B & 10.86 & 11.88 & & 11.24 & 12.14 & & \\
\hline LSD. $\% 5 \mathrm{~F}$ & & 0.63 & & & 0.9 & & \\
\hline LSD. \%5 B & & 0.68 & & & 0.7 & & \\
\hline $\mathrm{F} \times \mathrm{B}$ & & $\mathrm{ns}$ & & & $\mathrm{ns}$ & & \\
\hline
\end{tabular}

The sucrose (\%) varied between $15.3-16.07 \%$ and from 13.97 to $14.96 \%$, respectively under the $\mathrm{N}+\mathrm{K}_{2} \mathrm{O}$ fertilizers rates with and without boron. The highest increase of sucrose $(\%)$ compred to the control treatment was obtained at the highest $\mathrm{N}+\mathrm{K}_{2} \mathrm{O}$ rates combined with boron, whereas the lowest one was recorded under the lowest $\mathrm{N}+\mathrm{K}_{2} \mathrm{O}$ rates without boron application. This means that the best treatment is that of the highest $\mathrm{N}+\mathrm{K}_{2} \mathrm{O}$ rates combined with boron.

Egypt. J. Soil Sci. 56, No. 4 (2016) 
It increased sucrose (\%) in root of sugar beet by $9.4 \%$ over the control, and by $15.0 \%$ compared with the treatment received no boron addition. The increase of sucrose $(\%)$ at the lowest $\mathrm{N}+\mathrm{K}_{2} \mathrm{O}$ rates with boron was about $4.6 \%$ compared with that of without boron addition treatment $(5.0 \%)$.

As for protein $(\%)$, the obtained results showed that it varied between 10.88 $-13.13 \%$ and from 9.75 to $11.85 \%$, respectively under the $\mathrm{N}+\mathrm{K}_{2} \mathrm{O}$ fertilizers rates with and without boron. The highest increase of protein (\%) was obtained at the highest $\mathrm{N}+\mathrm{K}_{2} \mathrm{O}$ rates combined with boron compared with the control treatment, whereas the lowest one was recorded under the lowest $\mathrm{N}+\mathrm{K}_{2} \mathrm{O}$ rates without boron application. This proves that the best treatment is that of highest $\mathrm{N}+\mathrm{K}_{2} \mathrm{O}$ rates combined with boron. It increased the protein $(\%)$ in root of sugar beet by $21.3 \%$ over the control, and by $10.8 \%$ compared with the treatment of without boron addition. The increase of the protein $(\%)$ at the lowest $\mathrm{N}+\mathrm{N}+$ $\mathrm{K}_{2} \mathrm{O}$ rates with boron was about $6.1 \%$ compared with that of without boron addition treatment. The results indicate that boron increased the protein content of root by about $6.1-10.8 \%$.

Likewise, average values, over the two seasons, of the purity (\%) and total chlorophyll increased from $82.8 \%$ to $87.08 \%$ and from 727.5 to $816 \mathrm{mg} / \mathrm{g}$, respectively, with increasing $\mathrm{N}+\mathrm{K}_{2} \mathrm{O}$ rates from $75 \mathrm{~N}+50 \mathrm{~K}_{2} \mathrm{O} \mathrm{Kg} \mathrm{fed}$ to $150 \mathrm{~N}+100 \mathrm{~K}_{2} \mathrm{O} \mathrm{Kg} \mathrm{fed}{ }^{-1}$ with boron application, compared to the control treatment $(77.05 \%$ and $581 \mathrm{mg} / \mathrm{g})$, respectively. The corresponding values for the same treatments without boron application were from 80.28 to $83.12 \%$ and from 702 to $816 \mathrm{mg} / \mathrm{g}$ compared to the control treatment $74.36 \%$ and $571 \mathrm{mg} / \mathrm{g}$, respectively, for the purity $(\%)$ and total chlorophyll.

The increase of the above mentioned yield quality traits as a result of increasing $\mathrm{N}+\mathrm{K}_{2} \mathrm{O}$ fertilizers rates may be due to the importance of nitrogen and potassium role in increasing vegetative growth through enhancing leaf initiation, increment chlorophyll concentration in leaves which may reflected in improving photosynthesis process and increasing fresh root weight. The obtained increases with $\mathrm{K}$ application could be due to its role on carbohydrate and $\mathrm{N}$-metabolism, water absorption and transpiration in plant.

Mehran and Samad (2013) indicated that adding the highest level of K (114 $\mathrm{kg} \mathrm{K}_{2} \mathrm{O}$ ha $^{-1}$ ) under different rates of $\mathrm{N}$ significantly increased sucrose contents, recoverable sugar yield and some quality traits. . Increasing $\mathrm{N}$ and $\mathrm{K}$ fertilization had a significant effect on nutrients content and uptake of roots and foliage over two seasons.

These results are in the same trend of those of El-Sarag and Moselhy (2013) who showed that the maximum sucrose percent (18.64 and $18.87 \%$ was achieved by adding $100 \mathrm{Kg} \mathrm{K} 2 \mathrm{O}$ and $141 \mathrm{Kg} \mathrm{N}^{-1}$. Ali (2015) found that highest averages of purity were obtained from $140 \mathrm{~kg} \mathrm{~N} /$ fed with 120 and 150 $\mathrm{ppm}$ boron. It could be noticed that increasing $\mathrm{N}$ and $\mathrm{K}$ fertilizers rates significantly increased root growth and quality. Armin and Asgharipour (2011) 
reported that the highest root yield and sucrose concentration were obtained by spraying plants with $12 \%$ boric acid at 60 days after planting.

\section{Conclusion}

Application of urea + potassium sulfate fertilizers at high rates to soil alone or combined with boron foliar spry improved the soil properties (EC and $\mathrm{pH}$ ) of the saline sodic soil. It also increased the available nutrients in the soil as well as the macronutrients concentrations in sugar beet roots, which reflected on increasing root yield and its component, top and sugar yield and yield quality such as sucrose percent, sugar purity (\%), total chlorophyll content and protein percent in roots. The maximum yield and yield quality of sugar beet crop was obtained at application rate of $150 \mathrm{~kg} \mathrm{~N} \mathrm{fed}^{-1}+100 \mathrm{~kg} \mathrm{~K}_{2} \mathrm{O} \mathrm{fed}$, with boron foliar spry at rate of $0.5 \mathrm{Kg} \mathrm{fed}^{-1}$. Therefore this treatment could be recommended to obtain economical yield with satisfactory quality and to improve the soil fertility under the conditions of the studied area.

\section{References}

Abdel-Mawly, S. E. and Zanouny, I. (2004) Response of sugar beet (Beta vulgaric, L) to potassium application and irrigation with saline water. Ass. Univ. Bull. Environ. Res. 7 (1), 123- 136.

Ali, A. A. M. (2015) Sugar beet productivity as affected by nitrogen fertilizer and foliar spraying with boron. Int. Curr. Microbiol. App. Sci. 4 (4): 181- 196.

Amin, Gehan, A.M. (2005) Study of some agricultural practices on sugar beet M.Sc.Thesis, Fac. of Agric., Zagazig Univ.

AOAC, (1995) Association of Official Analytical Chemists. $16^{\text {th }}$ ed., Official Methods of Analysis. Washington. DC.

Armin, M. and Asgharipour, M.R. (2011) Effect of time and concentration of boron foliar application on yield and quality of sugar beet. Asian Journal of plant sciences $10(5), 307-311$

Ashraf, M.Y. and A.H. Khan. (1993) Effect of $\mathrm{NaCl}$ on nitrogen status of sorghum. In: "Current Development in Salinity and Drought Tolerance of Plants". (Naqvi, S.S.M., R. Ansari, T.J. Flower, A. R. Azmi, Ed.) pp. 84-88.

Azzazy, N.B. (2004) Effect of nitrogen and Boron fertilization on yield and quality of sugar beet under new reclaimed soil conditions. Egypt J. Appl. Sci., 19 (8), 230-238.

Buskiene, L. and Uselis, N. (2008) The influence of nitrogen and potassium fertilizers on the growth and yield of raspberries cv. Polans. J. Agron. Res. 6 (1), $27-35$.

Cooke, D.A. and Scott, R.K. (1993)" The Sugar Beet Crop". Chapman and Hall London, pp. 262- 265.

Cottenie, A., verloo, M., Velghe, G. and Cameriynck, R. (1982) "Chemical Analysis of Plant and Soil."Laboratory of analytical and Agrochemistry, State Univ., Ghent , Belgium. 
El-Sarag, E.I. and Moselhy, S. H. (2013) Response of Sugar Beet Quantity and Quality to Nitrogen and Potasium Fertilization under Sandy Soils Conditions. Asian Journal of Crop Science, 5, 295-303.

Hellal, F.A.; Taalab, A. S. and Safaa, A. M. (2009) Influence of nitrogen and boron nutrition balance and suger yield grown in calcareous soil. Ozean. J. of Appl. Sci. 2 (1), $1-10$.

Helmy, A. M. and Shaban, Kh. A. (2007) Response of peanuts to K fertilization and foliar spraying with Zinc and Boron under sandy soil conditions. Zagazig J. Agric. Res. 34 (4), 160- 176.

Herlihy, M. (1989) Effect of potassium on sugar accumulation in storage tissue. Proc. $21^{\text {st }}$ colloquium Int. Potash Institue.

Ibrahim M.M., Khalifa M.A., Zein F.I and Omar E.H. (2002) Yield and quality of sugar beet crop as affected by Mif to Late season drought and potassium fertilization at North Nile delta. Egypt J. Soil Sci. 42 (1), 87-102.

Jaszczolt, E, (1998) Effect of two methods of fertilizing sugar beet with trace elements on the yields of roots and sugar. Gazeta-Cukrownicza, 106, 232- 234.

Jordan, M.M., Navarro-Pedreno, J., Garcia-Sanchez, E., Mateu, J., Juan, P., (2004) Spatial dynamics of soil salinity under arid and semi-arid conditions: geological and environmental implications. Environ. Geol. 45, 448-45.

Khalifa M.R. and Ibrahim S.M. (1995) Effect of irrigation intervals under different soil salinity levels on yield, quality and water relations of sugar beet at Kafer ElSheikh Governorate. J.Agric. Res. Tanta univ. 21(4), 795-805.

Kim, H.T. (1996) "Soil Sampling, Preparation and Analysis". Marcal Dekker Inc. New York, P.391.

Kristek A., Biserka Stojić, Suzana Kristek (2006) Effect of the foliar boron fertilization on sugar beet root yield and quality. Agriculture-Scientific and Professional Review. 12 (1).

Lal, F., Lal, P. and Singh, M. (1979) Effect of Ca/B ratios in soil on the yield of Bajra grown on saline-sodic soils. J. Ind. Soc. Soil Sci., 27, 95-96.

Maas, E.V. (1986) Salt tolerance of plants. Appl. Agric. Res., 1(1), 12-26.

Mahmoud, A.A. (2011) Impact of some sulphur sources on ameliorating soil characters, wheat yield and grain quality under newly reclaimed saline soil conditions. Fayoum J. Agric. Res. \& Dev. 25 (1), 36- 48.

Mehran, S. and Samad, S. (2013) Study of potassium and nitrogen fertilizer levels on the yield of sugar beet in jolge cultivar. J. Nov. Appl. Sci. 2 (4), 94- 100.

Metzner, H.; Rau, H. and Senger, H. (1965) Determination of photosynthetic pigment. Mangel Mutanten von Chorella. Planta, (65), 186-191.

Noaman, M.N. (2004) Effect of potassium and nitrogen fertilizers on the growth and biomass of some halophytes grown under high levels of salinity. J. Agron., 3, 25-30.

Egypt. J. Soil Sci. 56, No. 4 (2016) 
Ouda, S.M.M. (2011) Response of sugar beet to $\mathrm{N}$ and $\mathrm{K}$ fertilizers levels under sandy soil conditions. Zagazig J. Agric. Res., 28, 275 - 297.

Oyinlola, E.Y. (2007) Effect of boron fertilizer on yield and oil content of three sunflower cultivars in the Nigerian Savanna. J. Agron., 6 (3), 421-426.

Pertti, J.M., (1985) Nitrification in forest soil of different $\mathrm{pH}$ as affected by urea, Amm S and potassium sulphate. J. Soil Biology and Biochemistry, 17 (3), 363-367.

Salem, A. Kh. And Khaled, A. Sh. (2012) Fodder beat productivity and quality under different levels of nitrogen and potassium fertilizers and hill spacing in sandy soil. Egypt .J. of Appl. Sci. 27 (2), 39 - 51.

Seadh, S.E., Farouk, S. and El-Abady, M.I. (2007) Response of sugar beat to potassium sulfate under nitrogen fertilizer levels in newly reclaimed soils conditions. African Crop Science Conference Proceeding. 8, 147- 154. Printed in El-Minia, Egypt.

Shaban, Kh . A., Abd-Kader, M.G. and Siam, H.S. (2012) Effect of nitrogen and potassium mixing rates and cultural practices on faba bean productivity in saline soils. Inter. J. Acad. Res. 4 (6), $181-188$.

Shaban, Kh, A., Abd El-Rahman, A.H. and El-Ghyadd, E. (2009) The combined effect of different nitrogenous fertilizers and inoculation with rhizobium on faba bean and its quality. J. Agric. Sci. Mansoura. Univ., 34 (4), 259-2607.

Shaban, Kh. A., Khalil, A.A. and Amira, A.M. (2013) Effect of sowing date and nitrogen, potassium fertilization on faba bean productivity in newly reclaimed saline soil of North Sinai. J. Soil Sci and Agric. Eng. Mansoura Univ. 4(9), 893- 904.

Shaban, Kh.A. and Negm, M.A. (2008) Effect of Zn and B foliar application to sugar beet gtown on a calcareous soil on root, sugar yield and nutrient tendencies. Egypt. J. Soil. Sci. 48 (1):

Singh, K.N. and Sharma, D.P. (2001) Response of wheat to nitrogen and potassium in saline soils. J. Exper. Agric. 37 (3), 417 - 427.

Snedecor, G.W. and W.G. Cochran (1980) "Statistical Methods" $7^{\text {th }}$ ed . IOWA, State Univ. U.S.A.

Tarek, G.A., Alaedeen, B.T. Hani, M.S. Buteos, I.H. and Yasin, A.A. (2008) Salt removal efficiency as influenced by phyto-amelioration of salt affected soils. $J$. of Food, Agric. and Envir., 6 (3\&4), 456- 460.

Wang, G. Dobermann, A. Witt, C. Sun, Q. and Fu, R. (2001) Performance of site-specific nutri ent manag ement of irrigated rice in southeast China. Agron. J. 93, 869-878. 


\title{
تأثيرالتسميد باليوريا وسلفات البوتاسيوم مع البورن على خصوبة
}

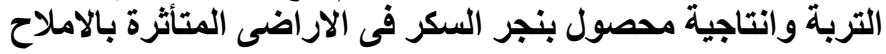

رانيا محمد الثنال

\author{
قسم الار اضى و المياة- كلية الزر اعة ـ جامعة طنطا ـ مصر
}

أجريت تجربة حقلية في القنطرة شرق، محافظة الإسماعيلية، مصر، خلال

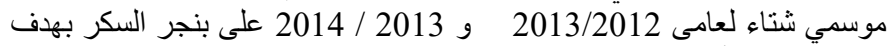

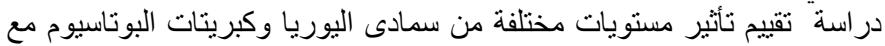

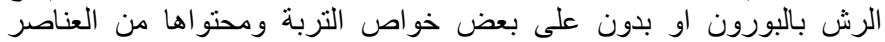

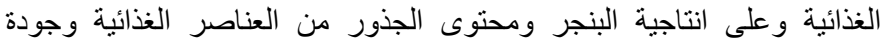
المحصول فى الاراضى المنأثرة بالاملاح.

واجريت التجربة فى ارض ملحية صودية =

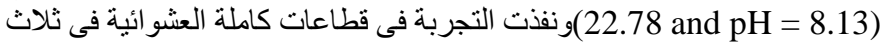
مكررات واشتملت معاملات التجربة على ثلاث معدلات معلات مختلفة من اليوريا

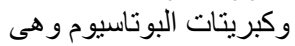

(75 kg N+ $50 \mathrm{~kg} \mathrm{~K} 2 \mathrm{O}, 100 \mathrm{~kg} \mathrm{~N}+75 \mathrm{~kg} \mathrm{~K} \mathrm{O}_{2} \mathrm{O}$ and $150 \mathrm{~kg}$ $\left.\mathrm{N}+100 \mathrm{~kg} \mathrm{~K}_{2} \mathrm{O}_{\text {fed }}{ }^{-1}\right)$

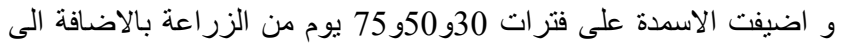

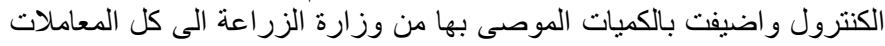

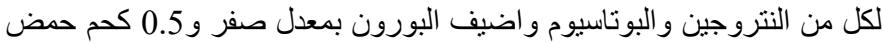

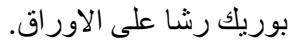

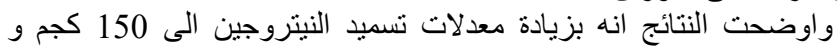

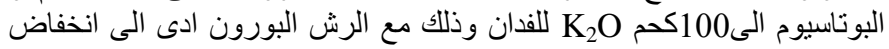

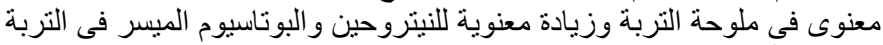

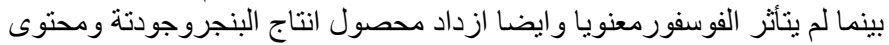

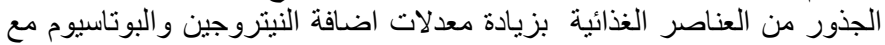

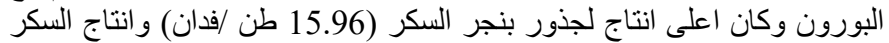

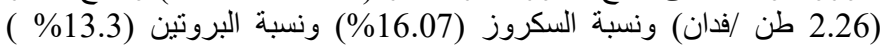

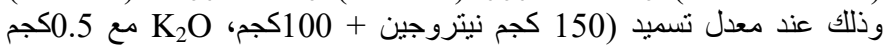

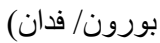

وايضا وجد ان اضافة معدلات الاسمدة من النيتروجين والبوتاسيوم كان لها

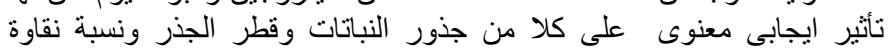

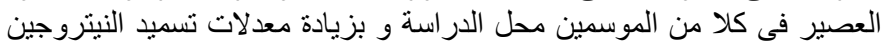
و الفوسفور مع البورن كانت هنال زيادة معنوية لمحتوى الجذور من النوات النيتروجين و البوتاسيوم والفوسفور خلال موسمى النمو. لهال

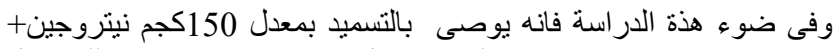

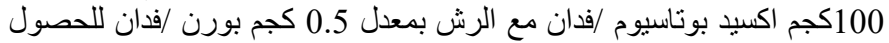

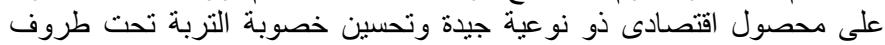

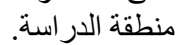

